\title{
A study on the characterization of deposited dust on HVAC ducts in subway stations
}

\author{
Joonsig Jung ${ }^{1}$, Duckshin Park ${ }^{2}$, , Soon-Bark Kwon ${ }^{2}$, Sungho Choi ${ }^{1}$, Seongmi Kim ${ }^{1}$, Wooseok Lee ${ }^{1}$, \\ Hyungjin Jeon ${ }^{3}$
}

${ }^{1}$ National Indoor Environment \& Noise Research Division, National Institute Environmental Research, Incheon, Korea

${ }^{2}$ Transportation Environmental Research Team, Korea Railroad Research Institute, Uiwang, Korea

${ }^{3}$ Division of Environmental Information Research, Korea Environment Institute, Seoul, Korea

\author{
Email address: \\ jjsfrog@hanyang.ac.kr (J. Jung), dspark@krri.re.kr (D. Park), sbkwoon@krri.re.kr (S. Kwon), cshchj@korea.kr (S. Choi), \\ seongmi@korea.kr (S. Kim), lee8080@korea.kr (W. Lee), hjjeon@kei.re.kr (H. Jeon)
}

\section{To cite this article:}

Joonsig Jung, Duckshin Park, Soon-Bark Kwon, Sungho Choi, Seongmi Kim, Wooseok Lee, Hyungjin Jeon. A Study on the Characterization of Deposited Dust on HVAC Ducts in Subway Stations. International Journal of Environmental Monitoring and Analysis.

Vol. 2, No. 6, 2014, pp. 320-327. doi: 10.11648/j.ijema.20140206.14

\begin{abstract}
This study used various methods to evaluate duct cleanliness and identify the levels of deposited dust in the HVAC systems of subway stations, as well as identifying the characteristics of the pollution sources at the stations. Levels of deposited dust were determined in two subway stations in Seoul from September 2011 to January 2012. The levels of dust deposited on ducts of the stations were measured by visual inspection, the quantitative vacuum test (VT), and the deposit thickness test (DTT). The VT results confirmed that no subway station exceeded a dust deposit of $1.0 \mathrm{~g} / \mathrm{m}^{2}$, which is the recommended surface contamination limit when using the VT method. However, in some supply ducts, the thickness of the dust layer exceeded $60.0 \mu \mathrm{m}$, the recommended surface contamination limit when using the DTT method. The visual inspection indicated that platform pollution in subway station A was higher than in the HVAC and waiting rooms, but the difference was insignificant $(\mathrm{p}=0.852)$. At subway station $\mathrm{B}$, the waiting room had a slightly higher level of deposited dust, but the difference was insignificant $(\mathrm{p}=0.438)$. The inspected areas were divided into HVAC rooms, return lines, and supply lines according to ventilation type. Although all three inspections revealed that return lines had the highest levels of deposited dust, the difference was insignificant. The correlation between the results of the visual inspection and VT methods, and between the results of visual inspection and DTT methods were both significant $(p>0.01)$ with $r=0.815$ and 0.818 , respectively. It was confirmed that the results of a qualitative visual inspection method corresponded relatively well with the results of the quantitative VT and DTT methods. Analyses of eight heavy metals in the HVAC systems of the subway stations indicated that the inclusion ratios of iron $(\mathrm{Fe})$, zinc $(\mathrm{Zn})$, and magnesium $(\mathrm{Mg})$ were $80.75-93.6 \%, 2.94-15.64 \%$, and 1.63-1.82\%, respectively. Traces of other heavy metals ( $\mathrm{As}, \mathrm{Cd}, \mathrm{Cu}, \mathrm{Pb}$, and $\mathrm{Cr}$ ) were also detected.
\end{abstract}

Keywords: HVAC System, Duct, Deposited Dust, Subway Station

\section{Introduction}

The US Environmental Protection Agency (EPA) suggests that cleaning the coils, fans, ducts, and heat exchangers of polluted cooling and heating systems improves the system performance, saves energy costs during the operation of the system, and extends the life of HVAC systems [1]. Moreover, the American Society of Heating, Refrigerating, and Air-Conditioning Engineers (ASHRAE) reports that cleaning HVAC systems reduces energy consumption by about $10 \sim 25 \%$ [2].
The pollutants inside ducts consist mostly of sand, soil, synthetic fibers, human hair and other fibers, and carbon particles such as smoke. Inorganics, including crystalline structures and organics such as fibers, are deposited inside supply ducts, while fibers are mostly deposited inside ventilation ducts and crystalline structures, including sand and carbon particles, tend to be deposited inside external air blowing ducts. Because of the structural characteristics of ducts, some of the pollutants deposited therein can be resuspended by the impact of vibrations and air flows generated during HVAC system operation. The dust is 
discharged indoors through the outlet and eventually increases the level of indoor pollution. Sometimes the duct surface is oiled to reduce friction, but the viscous oil remaining in the duct can accelerate the deposition of dust on the duct surface.

The cleaning of deposited material is particularly important because most ventilation ducts in Korea use the ceiling return method, which takes in outdoor air through the ceiling and recirculates it, thus making the deposition of pollutants inside the duct an even more serious concern. If the ventilation ducts are not cleaned, heavy metals and bacteria, which can be present in the deposited dust, will lower indoor air quality and have harmful effects on exposed individuals, possibly leading to respiratory diseases.

There are various ways of diagnosing the cleanliness of HVAC duct lines, but they can produce different results according to their principles and purposes [3-4]. Because Korea currently has no standards or guidelines for assessing duct cleanliness. Therefore, this study used various methods to evaluate duct cleanliness and identify the levels of deposited dust in the HVAC systems of subway stations, as well as identify the characteristics of the pollution sources at the stations.

\section{Materials and Methods}

The visual inspection method is the most basic test for evaluating the pollution levels in HVAC system ducts [5-7]. Although visual inspection can be subjective, it is used widely due to its low cost and enables the state of HVAC systems to be assessed rapidly.

VT is also widely used to evaluate the pollution levels in HVAC systems [8-9]. There are two types of vacuum test: a method in which a brush is mounted in the vacuum pump and is used to sweep the duct, allowing comparison of conditions before and after sweeping; and the National Air Duct Cleaners Association (NADCA) VT, which uses a system consisting of a pump with a $15 \mathrm{~L} / \mathrm{m}$ flow capacity, a $47-\mathrm{mm}$ mixed-cellulose-ester (MCE) filter, and a three-stage cassette holder. It involves fixation of a $0.381-\mathrm{mm}$-thick, $100-\mathrm{cm}^{2}$ template to the duct surface and measurement of the dust in the groove.

DTT method, a template with 20 holes is fixed onto the duct surface and the dust thickness in the duct is measured [6-7]. The dust thickness is measured in micrometers as the average of 20 samples. The properties of the various measuring methods and guideline are summarized in Table 1.

Levels of deposited dust were determined in two subway stations in Seoul from September 2011 to January 2012. Station A have a HVAC room, a waiting room, an office, and a transfer pathway on the first basement level and a platform on the second basement level. Station B have cultural facilities on the first basement level, a waiting room, an office, and a HVAC room on the second basement level, and a platform on the third basement level. There are two HVAC rooms at each station, and each HVAC room ventilate one-half of the subway station.
Table 1. Worldwide guidelines for cleanliness on HVAC ducts.

\begin{tabular}{|c|c|c|c|c|}
\hline \multirow{2}{*}{ Reference } & \multirow{2}{*}{ Areas } & \multicolumn{2}{|l|}{ Values } & \multirow{2}{*}{ Method } \\
\hline & & Prior & After & \\
\hline \multirow[t]{2}{*}{${ }^{10)} \mathrm{NADCA}, 1992$} & All Ducts & - & $0.1 \mathrm{~g} / \mathrm{m}^{2}$ & Vacuum \\
\hline & Supply/Reci & $1 \mathrm{~g} / \mathrm{m}^{2}$ & & Vacuum \\
\hline \multirow{3}{*}{${ }^{11)} \mathrm{HVCA}, 1998$} & rculation Air & $60 \mu \mathrm{m}$ & $0.1 \mathrm{~g} / \mathrm{m}^{2}$ & Thickness test \\
\hline & Exhaust Air & $6 \mathrm{~g} / \mathrm{m}^{2}$ & $0.1 \mathrm{~g} / \mathrm{m}$ & Vacuum \\
\hline & Exnaust AIr & $180 \mu \mathrm{m}$ & & Thickness test \\
\hline${ }^{12)}$ JADCA, 1997 & Supply Air & $1 \mathrm{~g} / \mathrm{m}^{2}$ & - & $\begin{array}{l}\text { Wiping with } \\
\text { cloth }\end{array}$ \\
\hline${ }^{13)}$ FISIAQ, 2001 & Supply Air & $\begin{array}{l}2 \mathrm{~g} / \mathrm{m}^{2} \\
5 \mathrm{~g} / \mathrm{m}^{2}\end{array}$ & - & $\begin{array}{l}\text { Scrape } \\
\text { Vacuum }\end{array}$ \\
\hline${ }^{14)} \mathrm{VDI}, 2006$ & General & $20 \mathrm{~g} / \mathrm{m}^{2}$ & $10 \mathrm{~g} / \mathrm{m}^{2}$ & $\begin{array}{l}\text { Scrape } \\
\text { Vacuum }\end{array}$ \\
\hline
\end{tabular}

Evaluation criteria of visual inspection were established based on previous studies and the results of the investigation conducted in this study. The pollution levels were classified into five grades according to the state of the pollution and its effect on ventilation: Grade 1 was clean; Grade 2 was slightly polluted; Grade 3 was polluted; Grade 4 was quite significantly polluted; and Grade 5 was heavily polluted, as shown in Table 2.

Table 2. Visual inspection method categories for the evaluation of duct cleanliness.

\begin{tabular}{llll}
\hline Point & Classification & State & Image \\
\hline 1 & Clean & No deposited dust detected & Some traces of deposited dust \\
2 & $\begin{array}{l}\text { Slightly } \\
\text { polluted }\end{array}$ & $\begin{array}{l}\text { Definite traces of deposited } \\
\text { dust detected, but no impact } \\
\text { on overall ventilation }\end{array}$ \\
3 & $\begin{array}{l}\text { Polluted } \\
\text { Definite traces of deposited } \\
\text { dust detected, with an impact } \\
\text { on overall ventilation }\end{array}$ & (4) \\
significantly & $\begin{array}{l}\text { Large amount of deposited } \\
\text { dust detected }\end{array}$ & \\
5 & Heavily & polluted &
\end{tabular}

For the DTT and VT methods, two samples were collected during each investigation of the supply and return lines, based on NADCA recommendations. A total of 64 samples was collected at the two subway stations.

Using a DTT (Elcometer 456 Duct Deposit Measuring Kit: Elcometer, Manchester, UK), a template was placed on the dust in the duct for measurement. Each template contained 20 measurement points that automatically measured the thickness of the dust layer, calculated the average, and stored it in the memory. For the VT method, the flow rate $(15 \mathrm{~L} / \mathrm{min})$ of the pump was calibrated before the samples were collected. The MCE filter paper was dried for approximately $48 \mathrm{~h}$ and its weight was measured. The filter paper was then mounted in a 37-mm cassette and connected to the pump. The samples were then collected at a flow rate of $15 \mathrm{~L} / \mathrm{min}$ from the points of the template $\left(100 \mathrm{~cm}^{2}\right)$ mounted on the duct surface. The samples of deposited dust were sealed in the cassette and transferred to the analysis room. They were dried for 
approximately 48 hours and weighed using an electronic scale. The concentration was calculated using the weight difference before and after sampling. The final weight was calibrated using a blank.

To assay heavy metals in the deposited dust, the surfaces of the ducts were swept with a brush to collect dust. Levels of eight heavy metals ( $\mathrm{Cd}, \mathrm{Cu}, \mathrm{Cr}, \mathrm{Pb}, \mathrm{Zn}, \mathrm{Ni}, \mathrm{Fe}$, and $\mathrm{Mg}$ ) were determined using a total concentration-based analysis according to the Korean Standard Test Method [15]. For heavy metal analyses, samples collected at each point were air-dried in a well-ventilated location without direct light and screened using a 100 mesh standard sieve. A 3 g sample was measured precisely to $0.001 \mathrm{~g}$ and placed in a $250 \mathrm{~mL}$ reaction vessel. Then, $21-\mathrm{mL} \mathrm{HCl}$ and $37-\mathrm{mL} \mathrm{HNO}$ were added, and the reaction vessels were left at room temperature for $\geq 2 \mathrm{~h}$ before being slowly heated to decompose the organic materials. The sample was filtered through a No. 40 filter paper, and $100 \mathrm{~mL}$ of the filtrate were analyzed by atomic absorption spectrometry (AAS: Varian spectraAA 220, Varian, Palo Alto, CA, USA).

Deposited dust samples were collected from a $100 \mathrm{~cm}^{2}$ area on the bottom of the duct using a brush. The individual who collected the samples wore a mask with a HEPA filter, as well as gloves and a dustproof gown.

Differences in the concentrations of heavy metals in the deposited dust between the subway stations were analyzed by t-tests and ANOVA using SPSS ver. 12.0 (SPSS Inc., USA). We analyzed the statistical significance of the correlation between the visual inspection and the other inspection methods. Differences were determined according to the type of ventilation and stations, using t-tests to verify the correlations with the variables.

\section{Results}

Tables $3 \mathrm{a}$ and $\mathrm{b}$ show the results of the visual, VT method, and DTT method inspections conducted separately according to the characteristics of the evaluation subway station. The average visual inspection grade at station A was $2.14 \pm 0.66$, and at station $\mathrm{B}$ was $2.05 \pm 0.87$. Although the average grade at station A was slightly higher, the difference was insignificant $(p=0.122)$. At station $A$, the average grade on the platform was slightly higher than in the HVAC and waiting rooms, but the difference was also insignificant ( $\mathrm{p}=$ 0.852). At station $\mathrm{B}$, only the waiting room and the platform were inspected because entry into the HVAC room was prohibited. The average grade in the waiting room was slightly higher, but the difference was again insignificant ( $\mathrm{p}=$ 0.438).

Table 3a. Visual inspection results of deposited dust on ducts in station A and B.

\begin{tabular}{lllllll}
\hline \multirow{2}{*}{ Station } & Sampling & \multirow{4}{*}{ Visual inspection (Unit: grade score) } \\
\cline { 4 - 7 } & site & & Mean \pm SD & Range & GM & p-value \\
\hline \multirow{4}{*}{ A } & HVAC room & 10 & $2.00 \pm 0.71$ & $1.0-3.0$ & 1.88 & \\
& Waiting room & 10 & $2.20 \pm 0.84$ & $1.0-3.0$ & 2.04 & 0.852 \\
& Platform & 8 & $2.25 \pm 0.50$ & $2.0-3.0$ & 2.21 & \\
& Total & 28 & $2.14 \pm 0.66$ & $1.0-3.0$ & 2.03 & 0.122 \\
& HVAC room & - & - & - & - & \\
B & Waiting room & 18 & $2.22 \pm 0.83$ & $1.0-3.0$ & 2.05 & 0.438 \\
& Platform & 18 & $1.88 \pm 0.92$ & $1.0-3.0$ & 1.68 & \\
& Total & 36 & $2.05 \pm 0.87$ & $1.0-3.0$ & 1.85 & \\
\hline
\end{tabular}

Table 3b. Measurement results of deposited dust on ducts in station A and B.

\begin{tabular}{|c|c|c|c|c|c|c|c|c|c|c|}
\hline \multirow{2}{*}{ Station } & \multirow{2}{*}{ Sampling site } & \multirow{2}{*}{$\mathbf{N}$} & \multicolumn{4}{|c|}{ VT method (Unit: $\mathrm{g} / \mathrm{m}^{2}$ ) } & \multicolumn{4}{|c|}{ DTT method (Unit: $\mu \mathrm{m})$} \\
\hline & & & Mean \pm SD & Range & GM & p-value & Mean \pm SD & Range & GM & p-value \\
\hline \multirow{4}{*}{ A } & HVAC room & 10 & $0.45 \pm 1.41$ & $0.28-0.61$ & 0.44 & 0.634 & $34.72 \pm 14.71$ & $13.57-49.45$ & 31.57 & 0.707 \\
\hline & Waiting room & 10 & $0.54 \pm 0.21$ & $0.41-0.92$ & 0.52 & & $34.70 \pm 14.71$ & $8.10-67.70$ & 31.87 & \\
\hline & Platform & 8 & $0.45 \pm 0.13$ & $0.30-0.59$ & 0.43 & & $44.49 \pm 85.3$ & $37.34-54.60$ & 43.88 & \\
\hline & Total & 28 & $0.49 \pm 0.16$ & $0.29-0.93$ & 0.46 & $0.002(\mathrm{~A})$ & $39.28 \pm 16.43$ & $8.10-67.70$ & 34.80 & $0.084(\mathrm{~A})$ \\
\hline \multirow{3}{*}{ B } & HVAC room & - & - & - & - & - & - & - & - & \\
\hline & Platform & 18 & $0.40 \pm 0.33$ & $0.03-0.86$ & 0.23 & & $24.03 \pm 20.17$ & $5.54-54.24$ & 17.01 & \\
\hline & Total & 36 & $0.48 \pm 0.30$ & $0.03-0.87$ & 0.34 & & $28.71 \pm 22.34$ & $5.54-83.29$ & 21.12 & - \\
\hline
\end{tabular}

+ HVCA (1998) guide values: - VT method: prior to measurement $1 \mathrm{~g} / \mathrm{m}^{2}$, after measurement $0.1 \mathrm{~g} / \mathrm{m}^{2}$. - DTT method: prior to measurement $60 \mu \mathrm{m}$.

In neither station did the VT result exceed $1.0 \mathrm{~g} / \mathrm{m}^{2}$, which is the recommended surface contamination limit for a HVAC system using the VT method [11]. In some supply duct lines the dust layer exceeded a depth of $60.0 \mu \mathrm{m}$, which is the recommended limit using the DTT method. A quantitative inspection of the surface contamination measured using the VT method confirmed that the geometric means (GM) of the total deposited dust in stations A and B were $0.46 \mathrm{~g} / \mathrm{m}^{2}$ and $0.34 \mathrm{~g} / \mathrm{m}^{2}$, respectively, indicating a 1.35 -fold greater quantity of deposited dust in station $\mathrm{A}$ than in station $\mathrm{B}$ $(p>0.01)$. The surface contamination levels of the HVAC room, the waiting room, and the platform in station A were $0.44 \mathrm{~g} / \mathrm{m}^{2}, 0.52 \mathrm{~g} / \mathrm{m}^{2}$, and $0.43 \mathrm{~g} / \mathrm{m}^{2}$, respectively, while the corresponding values for the waiting room and the platform of station B were $0.50 \mathrm{~g} / \mathrm{m}^{2}$ and $0.23 \mathrm{~g} / \mathrm{m}^{2}$, respectively; all differences were insignificant $(p=0.634,0.260)$.

The DTT method results indicated that the depth of the dust layer in station A (GM: $34.80 \mu \mathrm{m}$ ) was 1.64-fold that of station B (GM: $21.12 \mu \mathrm{m})$, but the difference was insignificant $(\mathrm{p}=$ 0.084). The depth of dust on the platform (GM: $43.88 \mu \mathrm{m}$ ) was 1.4- and 1.38-fold higher than in the HVAC room (GM: 31.57 $\mu \mathrm{m})$ and the waiting room (GM: $31.87 \mu \mathrm{m})$, respectively, at station $\mathrm{A}$, while the corresponding value in the waiting room (GM: $26.23 \mu \mathrm{m}$ ) was 1.54-fold higher than that on the platform (GM: $17.01 \mu \mathrm{m})$ at station B. However, all differences were insignificant $(p=0.707,0.462)$. 
Table 4 shows the results of the visual VT method, and DTT method inspections in the HVAC room, the return line, and the supply line. Although the return line had the highest deposited dust concentration with all three methods, the differences were insignificant $(p=0.200,0.197$, and 0.710). The visual inspection results indicated that the return line (GM: 2.71) had approximately 1.44- and 1.48-fold greater quantities of deposited dust than the HVAC room (GM: 1.88) and the supply line (GM: 1.83), respectively. The VT method results indicated that the return line (GM: $0.66 \mathrm{~g} / \mathrm{m}^{2}$ ) had approximately 1.50 - and 1.89-fold greater surface contamination than the HVAC room (GM: $\left.0.44 \mathrm{~g} / \mathrm{m}^{2}\right)$ and the supply line (GM: $0.35 \mathrm{~g} / \mathrm{m}^{2}$ ), respectively. The DTT method results revealed that the thickness of the dust layer in the return line (GM: $39.86 \mu \mathrm{m})$ was approximately 1.26 - and 1.70-fold higher than in the HVAC room (GM: $31.57 \mu \mathrm{m})$ and supply line (GM: $23.49 \mu \mathrm{m}$ ), respectively.5. Reference

Table 4. Investigation of deposited dust on ducts in station using VI, VT and DTT method

\begin{tabular}{llllll}
\hline Method & Site(N) & Mean \pm SD & Range & GM & p-value \\
\hline & HVAC & $2.00 \pm 0.70$ & $1.0-3.0$ & 1.88 & \\
VI & Return & $2.75 \pm 0.50$ & $2.0-3.0$ & 2.71 & 0.200 \\
(unit: score) & Supply & $2.00 \pm 0.79$ & $1.0-3.0$ & 1.83 & \\
& Total & $2.09 \pm 0.77$ & $1.0-3.0$ & 1.93 & \\
& HVAC & $0.45 \pm 0.12$ & $0.29-0.61$ & 0.44 & \\
VT & Return & $0.69 \pm 0.22$ & $0.41-0.87$ & 0.66 & \multirow{2}{*}{0.197} \\
(unit: g/m $)$ & Supply & $0.45 \pm 0.26$ & $0.04-0.93$ & 0.35 & \\
& Total & $0.48 \pm 0.24$ & $0.04-0.93$ & 0.39 & \\
& HVAC & $34.70 \pm 14.71$ & $13.57-49.45$ & 31.57 & \\
DTT & Return & $40.94 \pm 10.25$ & $27.12-51.72$ & 39.86 & \multirow{2}{*}{0.710} \\
(unit: $\mu \mathrm{m})$ & Supply & $31.71 \pm 22.76$ & $5.54-83.29$ & 23.49 & \\
& Total & $33.33 \pm 20.38$ & $5.54-83.29$ & 26.28 & \\
\hline
\end{tabular}

Table 5 shows the results of a correlation analysis of the deposited dust determination methods. The correlation coefficients between the results of visual inspection and the VT method, and the results of visual inspection and the DTT method were $r=0.815$ and $r=0.818$, respectively, which were both significant $(\mathrm{p}>0.01)$.

The correlation between the VT method and the DTT method was $\mathrm{r}=0.673(\mathrm{p}>0.01)$. The regression slope between visual inspection and the DTT method was $\mathrm{Y}=$ $0.031 \mathrm{X}+1.054$ : the regression slope between visual inspection and the VT method was $\mathrm{Y}=2.457 \mathrm{X}+0.857$; and the regression slope between the VT method and the DTT method was $\mathrm{Y}=0.008 \mathrm{X}+0.212$. This confirms that the results of a qualitative visual inspection correspond relatively well to those of the quantitative VT and DTT methods (Figures 1, 2, and 3).

Table 5. Correlation analysis of the deposited dust using VI and DTT method.

\begin{tabular}{llll}
\hline & Visual inspection & VT method & DTT method \\
\hline Visual inspection & 1.00 & $0.815^{* *}$ & $0.818^{* *}$ \\
VT method & & 1.00 & $0.673^{* *}$ \\
DTT method & & & 1.00 \\
\hline
\end{tabular}

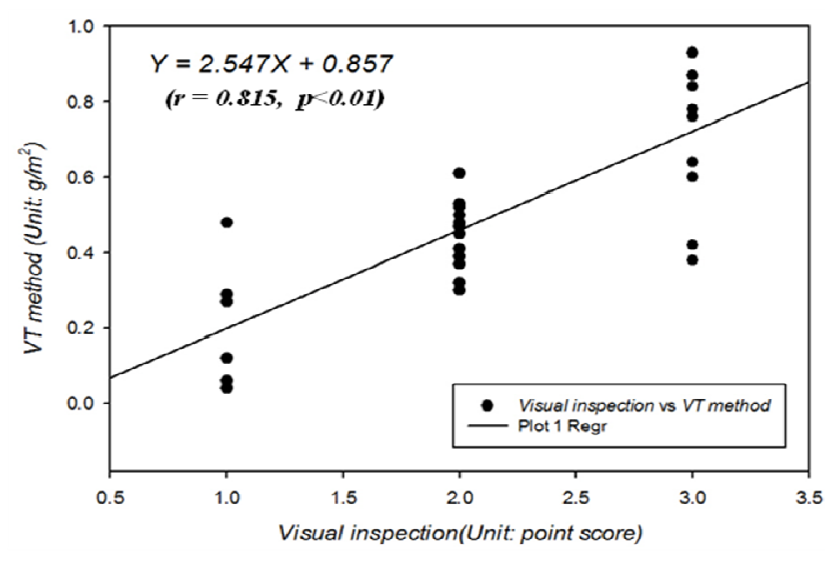

Figure 1. Correlation between VI and VT method

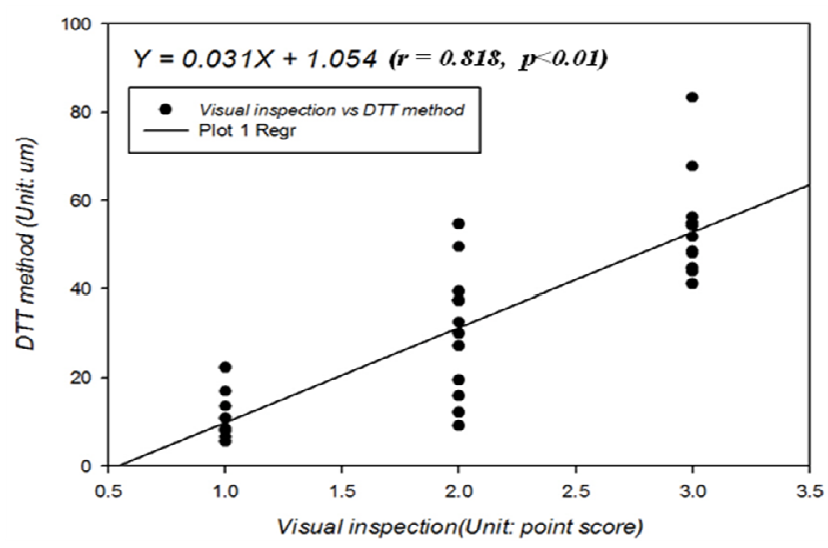

Figure 2. Correlation between VI and DTT method

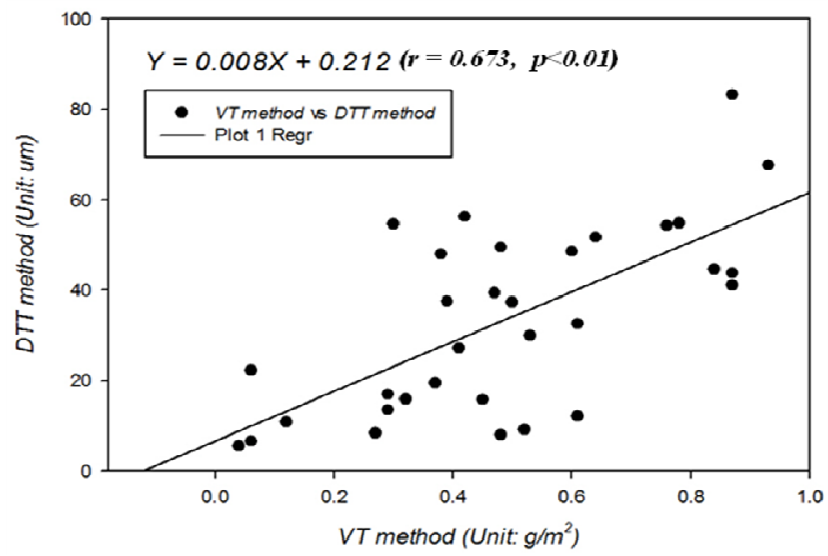

Figure 3. Correlation between VI and VT method

Table 6 summarizes the heavy metal concentrations in the deposited dust in the HVAC facilities of subway stations. At both stations $\mathrm{A}$ and $\mathrm{B}$ the highest concentrations were found for $\mathrm{Fe}$ at $203,782.74 \mathrm{mg} / \mathrm{kg}$ and $184,278.244 \mathrm{mg} / \mathrm{kg}$, respectively; followed by $\mathrm{Zn}$ at $39,475.86 \mathrm{mg} / \mathrm{kg}$ and $5,797.06 \mathrm{mg} / \mathrm{kg}$, respectively; and $\mathrm{Mg}$ at $4,594.35 \mathrm{mg} / \mathrm{kg}$ and $3,216.69 \mathrm{mg} / \mathrm{kg}$, respectively. The inclusion ratios of iron $\mathrm{Fe}$, $\mathrm{Zn}$, and magnesium $\mathrm{Mg}$ were $80.75-93.6 \%, 2.94-15.64 \%$, and $1.63-1.82 \%$, respectively. Traces of other heavy metals (As, $\mathrm{Cd}, \mathrm{Cu}, \mathrm{Pb}$, and $\mathrm{Cr}$ ) were also found (Figure 4). 

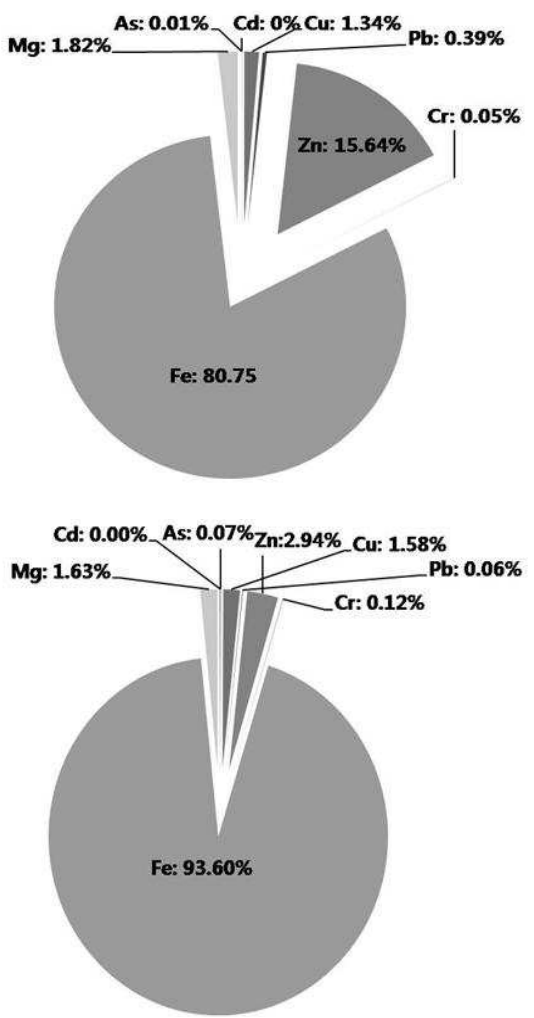

Figure 4. Comparison of heavy metal concentrations on HVAC system for station $A$ and $B$.

\section{Discussion}

This study used various methods to evaluate duct cleanliness and identify the levels of deposited dust in the HVAC systems of subway stations, as well as identifying the characteristics of the pollution sources at the stations. This study used qualitative visual inspection, and the quantitative VT and DTT methods used in previous studies to measure the levels of deposited dust in the HVAC systems of subway stations. Although visual inspection is the most widely used method of diagnosing duct pollution [5-7] it has limitations associated with the individual error. To qualitatively assess the level of dust pollution on ducts, it was categorized into five grades: Grade 1 was clean; Grade 2 was slightly polluted; Grade 3 was polluted; Grade 4 was quite significantly polluted; and Grade 5 was heavily polluted. Holopainen et al. (2002) evaluated the pollution levels on ducts according to six surface contamination levels $(<0.1,0.1,0.7,1.0,1.5$, and $\left.4.0 \mathrm{~g} / \mathrm{m}^{2}\right)$ using a visual inspection and the VT method, but stressed that a skilled tester was needed [9]. The VT method can be undertaken either using a brush connected to a vacuum pump or by following the NADCA VT method [9]. The latter has been adopted more widely. The DTT method evaluates the thickness of the deposited dust layer using 20 templates [6].

Table 6. Statistical summary of heavy metal concentrations on HVAC systems in stations

\begin{tabular}{|c|c|c|c|c|}
\hline Station & & Mean \pm SD & Range & GM \\
\hline \multirow{7}{*}{$\begin{array}{l}\mathrm{A} \\
(\mathrm{N}=28)\end{array}$} & As & $13.43 \pm 12.49$ & ND-39.12 & - \\
\hline & $\mathrm{Cd}$ & $2.62 \pm 1.20$ & $0.23-4.82$ & 2.19 \\
\hline & $\mathrm{Cu}$ & $3,388.19 \pm 2,550.85$ & $561.77-8,435.93$ & $2,329.23$ \\
\hline & $\mathrm{Pb}$ & $980.39 \pm 1,448.61$ & $133.30-5,619.82$ & 595.02 \\
\hline & $\mathrm{Zn}$ & $39,475.86 \pm 39,568.46$ & $6972.54-146,960.10$ & $26,694.40$ \\
\hline & $\mathrm{Cr}$ & $130.82 \pm 61.50$ & $13.19-269.91$ & 110.97 \\
\hline & $\mathrm{Mg}$ & $4,594.35 \pm 1,111.83$ & $2,556.74-5,922.58$ & $4,458.29$ \\
\hline \multirow{7}{*}{$\begin{array}{l}\mathrm{B} \\
(\mathrm{N}=36)\end{array}$} & As & $137.38 \pm 31.12$ & $75.48-174.16$ & 133.72 \\
\hline & $\mathrm{Cd}$ & $2.36 \pm 1.12$ & $1.09-4.64$ & 2.13 \\
\hline & $\mathrm{Cu}$ & $3,117.61 \pm 1,425.23$ & $1,178.69-6,909.38$ & $2,848.50$ \\
\hline & $\mathrm{Pb}$ & $119.18 \pm 50.60$ & $36.01-214.40$ & 108.49 \\
\hline & $\mathrm{Zn}$ & $5,797.06 \pm 5,839.60$ & $1,181.59-23,230.25$ & $4,086.11$ \\
\hline & $\mathrm{Cr}$ & $244.25 \pm 65.11$ & $117.30-342.16$ & 235.20 \\
\hline & $\mathrm{Mg}$ & $3,216.69 \pm 820.35$ & $1,631.14-4,643.38$ & $3,108.26$ \\
\hline
\end{tabular}

The VT method confirmed the surface contamination due to deposited dust to be $0.46 \mathrm{~g} / \mathrm{m}^{2}$ and $0.34 \mathrm{~g} / \mathrm{m}^{2}$ at stations A and $\mathrm{B}$, respectively $(\mathrm{p}>0.01)$. The HVAC room, the waiting room, and the platform at station $\mathrm{A}$ had surface contamination levels of $0.44 \mathrm{~g} / \mathrm{m}^{2}, 0.52 \mathrm{~g} / \mathrm{m}^{2}$, and $0.43 \mathrm{~g} / \mathrm{m}^{2}$, respectively. The waiting room and the platform at subway station B had surface contamination levels of $0.50 \mathrm{~g} / \mathrm{m}^{2}$ and $0.23 \mathrm{~g} / \mathrm{m}^{2}$, respectively. The results of the DTT method showed that station A (GM: $34.80 \mu \mathrm{m})$ had a dust layer 1.64-fold deeper than that at station B (GM: $21.12 \mu \mathrm{m})$, but the difference was insignificant $(\mathrm{p}=0.084)$. The platform (GM: $43.88 \mu \mathrm{m}$ ) had a dust layer 1.40- and 1.38-fold deeper than in the HVAC room (GM: $31.57 \mu \mathrm{m})$ and the waiting room (GM: $31.87 \mu \mathrm{m})$, respectively, at station $\mathrm{A}$, while in station B, the waiting room (GM: $26.23 \mu \mathrm{m})$ had a dust layer 1.54-fold deeper than the platform (GM: $17.01 \mu \mathrm{m})$ at station B. However, all differences were insignificant $(\mathrm{p}=0.707$, 0.462). At neither station did the VT result exceed the 1.0 $\mathrm{g} / \mathrm{m}^{2}$ surface contamination level recommended for HVAC systems when using the VT method [11]. In some supply ducts, the depth of the dust layer exceeded $60.0 \mu \mathrm{m}$, which is the recommended limit using the DTT method. Guidelines on when ducts should be cleaned differ according to country, but most countries recommend cleaning when the deposited dust 
concentration is $1.0 \mathrm{~g} / \mathrm{m}^{2}$ or greater or the thickness of the deposited dust layer exceeds $60 \mu \mathrm{m}$ [10-11]. Pasanen et al. (1998) reported that dust may accumulate up to a surface concentration of $5.1 \mathrm{~g} / \mathrm{m}^{2}$ in some structures [8].

The inspection of HVAC rooms, return lines, and supply lines using the VT method showed that the return line had the highest concentration of deposited dust. The results of the visual inspection indicated that the return line (GM: 2.71) had approximately 1.44- and 1.48-fold more deposited dust than the HVAC room (GM: 1.88) and the supply line (GM: 1.83), respectively. The VT method results indicated that the return line (GM: $0.66 \mathrm{~g} / \mathrm{m}^{2}$ ) had a surface concentration that was 1.50- and 1.89-fold higher than the HVAC room (GM: $0.44 \mathrm{~g} / \mathrm{m}^{2}$ ) and the supply line (GM: $0.35 \mathrm{~g} / \mathrm{m}^{2}$ ), respectively. The results of the DTT method revealed that the result line (GM: $39.86 \mu \mathrm{m}$ ) had a dust layer that was approximately 1.26 and 1.70-fold higher than the HVAC room (GM: $31.57 \mu \mathrm{m})$ and the supply line (GM: $23.49 \mu \mathrm{m})$, respectively. The return line had a high concentration of deposited dust due in part to the characteristics of the HVAC system, in which the level of dust deposition tends to increase in the presence of factors that interrupt the air flow, such as poor air supply velocity, duct surface roughness, the bending of ducts, and the presence of diffusers and dampers. Moreover, indoor air pollution in subway stations tends to increase with the depth of the station, which suggests that both improper management of the HVAC system and indoor air pollution affect dust deposition. It is likely that pollutants will accumulate on ducts. Jung and Ahn (2003) measured the concentration of microorganisms in buildings before and after cleaning and reported an average $31.4 \%$ decrease in the microorganism concentration following cleaning [16]. Foarde et al. (1996) reported that dust accumulation has a major impact on the propagation of bacteria under conditions of $90 \%$ humidity and $10-20 \mathrm{~g} / \mathrm{m}^{2}$ accumulated dust [17].

This study investigated only the parts of ducts in subway stations that were considered to be obstacles and work spaces in the ceiling. However, it is likely that this investigation was sufficient to determine the general trend of pollution due to deposited dust. The stations selected for the study contained many electrical systems and communication devices, as well as cooling/heating water pipes. The ceiling heights were low, and there were few access holes. These factors limited the evaluation of all pollution sources.

A correlation analysis of the deposited dust evaluation methods produced strong correlation coefficients between the results of visual inspection and the VT method and the results of visual inspection and the DTT method of $r=0.815$ and $r=$ 0.818 , respectively, which were both significant $(p>0.01)$.

The correlation coefficient between the VT and DTT results was $r=0.673(p>0.01)$. This study confirmed that the results of a qualitative visual inspection correspond relatively well to the results produced by quantitative methods. Holopainen et al. (2002) compared the results of a visual inspection and the VT method, and reported a correlation efficiency of $\mathrm{R}^{2}=0.95$, which was highly significant [9]. Rauno et al. (2002) evaluated the pollution level of dust deposited inside ducts using three methods (tape, vacuum, and optical methods) [18].. The correlation coefficient between the tape method and the vacuum method was $\mathrm{R}^{2}=$ 0.3 , and there was no correlation between the optical and vacuum methods. Although the best way to determine when cleaning is necessary is to evaluate duct pollution using the quantitative VT and DTT methods, there are practical constraints. As this study confirmed that the results of a qualitative visual inspection can correspond to the results of the quantitative VT and DTT methods, the visual inspection method could be more efficient, if the tester is skilled and experienced enough to objectively evaluate the pollution level, and visible data (pictures, video, etc.) are available.

The analysis of heavy metal concentrations indicated that $\mathrm{Fe}$ was the most abundant metal in the dust from both stations $\mathrm{A}$ and $\mathrm{B}$, followed by $\mathrm{Zn}$ and magnesium $\mathrm{Mg}$. The inclusion ratios of $\mathrm{Fe}, \mathrm{Zn}$, and $\mathrm{Mg}$ were $80.75-93.6 \%$, $2.94-15.64 \%$, and $1.63-1.82 \%$, respectively. Traces of other heavy metals ( $\mathrm{As}, \mathrm{Cd}, \mathrm{Cu}, \mathrm{Pb}$, and $\mathrm{Cr}$ ) were also detected.

The inclusion rates of $\mathrm{Fe}$ and $\mathrm{Zn}$ were high due to the material from which the duct pipes were constructed. Ducts are generally composed of galvanized steel, which is a steel plate coated with zinc to make it rust resistant. Over time, rust develops as the duct material corrodes, which increases the inclusion rate.

Park et al. (2013) evaluated the $\mathrm{PM}_{10}$ concentration in the subway stations of Seoul metropolitan city and reported that $\mathrm{Fe}$ originated from the corrosion of rails or wires [19]. Other studies have reported that the oxidized $\mathrm{Fe}\left(\mathrm{Fe}_{3} \mathrm{O}_{4}\right)$ found in the dust of subway stations is more toxic than $\mathrm{Fe}$ in the atmosphere [20]. Although some of the Fe content in subway stations is generated by brakes, wheels, rails, and electrical wires, a portion in the air is likely generated by ventilation duct corrosion. Therefore, additional exposure studies are required. Federico et al. (2009) analyzed the heavy metals in dust found in HVAC filters and reported a $\mathrm{Pb}$ concentration of 5.4-28 $\mu \mathrm{g} / \mathrm{g}$, which was higher than the levels of $\mathrm{Cd}$, As, and $\mathrm{Zn}$ [21], the principal heavy metals detected [22-24].

\section{Conclusion}

This study used various methods to evaluate duct cleanliness and identify the levels of deposited dust on the HVAC systems in subway stations, as well as identifying the characteristics of the pollution sources at the stations. The VT results confirmed that no subway station exceeded a dust level of $1.0 \mathrm{~g} / \mathrm{m}^{2}$, which is the recommended surface contamination limit using the VT method. However, in some supply ducts, the thickness of the dust layer exceeded 60.0 $\mu \mathrm{m}$, the recommended surface contamination limit using the DTT method.

The average visual inspection grade of station A was 2.14 \pm 0.66 , while for station B it was $2.05 \pm 0.87$. Although the average grade at station A was slightly higher, the difference was insignificant $(p=0.122)$. In station $A$, the platform had a slightly higher average grade than the HVAC waiting rooms, but the difference was also insignificant $(\mathrm{p}=0.852)$. At 
station $\mathrm{B}$, the waiting room had a slightly higher average grade following the visual inspection result, but the difference was again insignificant $(\mathrm{p}=0.438)$.

Although the return line had the highest deposited dust concentration for all three methods, the differences were insignificant $(\mathrm{p}=0.200,0.197,0.710)$. The visual inspection indicated approximately 1.44 - and 1.48 -fold greater quantities of deposited dust in the return line than in the HVAC room and the supply line, respectively. The VT method results indicated that the return line had a surface contamination level that was approximately 1.50 - and 1.89-fold higher than in the HVAC room and the supply line, respectively. The DTT method results revealed that the depth of the dust layer in the return line was approximately 1.26and 1.70-fold higher than in the HVAC room and the supply line, respectively. This confirms that the results of a qualitative visual inspection correspond relatively well to the results of the quantitative VT and DTT methods.

The correlation between both the visual inspection method and the VT method, and between the visual inspection method and the DTT method, were significant $(p>0.01)$ at $r$ $=0.815$ and $r=0.818$, respectively. It was confirmed that the results of a qualitative visual inspection method corresponded relatively well with the results of the quantitative VT and DTT methods.

Analyses of heavy metals indicated that $\mathrm{Fe}$ was the most abundant metal in the dust of both stations A and B, followed by $\mathrm{Zn}$ and magnesium $\mathrm{Mg}$. The inclusion ratios of iron $\mathrm{Fe}$, $\mathrm{Zn}$, and $\mathrm{Mg}$ were $80.75-93.6 \%, 2.94-15.64 \%$, and $1.63-1.82 \%$, respectively. Traces of other heavy metals (As, $\mathrm{Cd}, \mathrm{Cu}, \mathrm{Pb}$, and $\mathrm{Cr}$ ) were also detected.

\section{Acknowledgements}

The work described in this paper was supported by research grants on the Basic Research Project of Korea by Ministry of Science, ICT, and Future Planning, and Railway Technology Research Project by Minister of Land, Infrastructure and Transport (14RTRP-B081249-01).

\section{References}

[1] EPA, "Should you have the air ducts in your home cleaned?," EPA-402-K-97-002, Research Triangle Park: U.S. Environmental Protection Agency, Indoor Environment Division, Office of Air and Radiation, 1997.

[2] ASHRAE, "Gravimetric and Dust-spot Procedures for Testing Air-cleaning Devices Used in General Ventilation for Removing Particulate Matter," Atlanta, American Society of Heating, Refrigerating, and Air-conditioning Engineers, Inc. (ANSI/ASHRAE Standard 52.1-1992), 1992.

[3] J. I. Fransson, S. H. Ruud, and L. Rosell, "Rena ventilationskanaler", SP-Rapport: 38, SverigesProvningsochForskningsinstitut (SP), Energiteknik/KemiskAnalys, Borås, Sweden, 1995.

[4] B. Müller, K. Fitzner, and V. Küchen, “Airless, a European Project on HVAC Systems: Maintenance of HVAC-Systems
Task Two". In: Raw, G., Aizlewood, C. and Warren, P. (eds) Proceedings of Indoor Air '99, Edinburgh, The 8th International Conference on Indoor Air Quality and Climate 1, pp. 355-360, 1999.

[5] NADCA, "Assessment, cleaning and restoration of HVAC systems: An industry standard for HVAC cleaning professionals", 2006.

[6] HVCA, "Guide to good practice: Internal cleanliness of ventilation systems. (HVCA TR19)," Heating and Ventilating Contractors' Association (HVCA), London. UK, 2005.

[7] L. M. Brosseau, D. Vesley, T. H Kuehn, J. Melson, and H. S. Han, "Dust cleaning: a review of associated health effects and results of company and expert surveys," ASHRAE Transactions 106, pp. 180-187, 2000.

[8] P. Pasanen, "Emissions from the filters and hygiene of air ducts in the ventilation systems of office buildings," Doctoral dissertation, University of Kuopio, Japan, 1998.

[9] R. Holopainen, V. Asikainen, P. Pasanen, and O. Seppanen, "The field comparison of three measuring techniques for evaluation of the surface dust level in ventilation ducts," Indoor Air, vol. 12, pp. 47-54, 2002.

[10] NADCA, "Mechanical cleaning of non porous air conveyance system components $01, " 11 \mathrm{p}, 1992$.

[11] HVCA, "Cleanliness of Ventilation Systems, Guide to good practice," TR/17. Heating and Ventilating Contractors' Association. London, UK, 1998.

[12] JADCA (S. Yoshizawa, H. Ito, K. Kumagai, K. Shizawa, S. Shimizu, S. Abe, and T. Ichiki), "Methods to evaluate the duct cleaning efficiency," Research Report of the Japan Air Duct Cleaners Association, Tokyo, Japan, JADCA, 1997.

[13] FiSIAQ, "The Classification of Indoor Climate (2000)," FISIAQ publication 5E, The Finnish Society of Indoor Air Quality and Climate (FiSIAQ), Espoo, Finland. 40p, 2001

[14] VDI 6022 (4/2006/Draft), "Hygiene requirements for ventilation and air conditioning systems and units," Measuring methods Part 2, pp. 6, 2006.

[15] Korean Ministry of Environment, "Standard methods for contamination soil," URL: http//www.konetic.or.kr, 2013.

[16] Y. H. Jung, and B. W. Ahn, "Experiments on contamination in air duct and air handling unit," J. Korean Soc. Living Environ. Sys, vol. 10(1), pp. 41-46, 2003.

[17] K. Foarde, and M. Menetrez, "Evaluating the potential efficacy of three antifungal sealants of duct liner and galvanized steel as used in HVAC systems," Journal of Industrial Microbiology \& Biotechnology, vol. 29, pp. 38-43, 2002.

[18] H. Rauno, A. Vesa, P. Pertti, and S. Olli, "The Field Comparison of Three Measuring Techniques for Evaluation of the Surface Dust Level in Ventilation Ducts," Indoor Air, vol. 12, pp. 47-54, 2002.

[19] S. B. Park, S. Na, T. J. Lee, H. K. Ko, S. J. Bae, S. D. Kim, D. S. Park, J. R. Sohn, and D. S. Kim, "Identification of PM10 Chemical Characteristics and Sources and Estimation of their Contributions in a Seoul Metropolitan Subway Station," Journal of Korean Society for Atmospheric Environment, vol. 29(1), pp. 74-85, 2013. 
[20] H. L. Karlsson, L. Nilsson, and L. Moller, "Subway particles are more genotoxic than street particles and induce oxidative stress in cultured human lung cells," Chemical Research in Toxicology, vol. 18, pp. 19-23, 2005.

[21] N. Federico, A. S. Jeffrey, and A. K. Kerry, "Biological and Metal Contaminants in HVAC Filter Dust," ASHRAE Transactions 115, part 2, 2009

[22] M. A. Rajhi, M. R. Seaward, and A. S. Aamer, "Metal levels in indoor and outdoor dust in Riyadh, Saudi Arabia," Environment International, vol. 22, pp. 315-324, 1996.
[23] M. Lisiewicz, R. Heimburger, and J. Golimowski, "Granulometry and the content of toxic and potentially toxic elements in vacuum-cleaner collected, indoor dusts of the city of Warsaw," Science of the Total Environment, vol. 263, pp. 69-78, 2000.

[24] A. Turner, and L. Simmonds, "Elemental concentrations and metal bioaccessibility in UK household dust," Science of the Total Environment, vol. 371, pp. 74-81, 2006. 